\title{
'I Am the LORD your Healer' Exodus 15:26 (אנייהוהרפאך): Healing in the Old Testament and the African (Yoruba) context
}

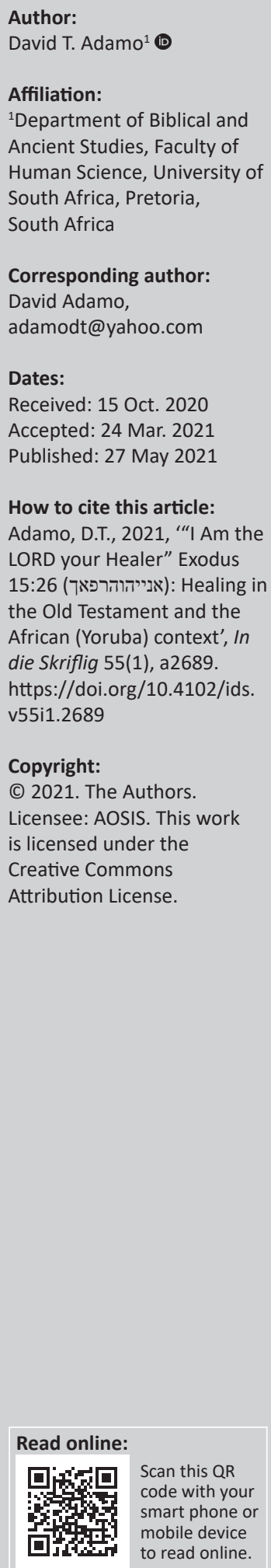

When one examines the concept of healing in the Old Testament and African (Yoruba) context, it is apparently quite important, but when one examines prestigious books on the Old Testament theology, it appears to be difficult to find a major section on God as a healer or significant discussion on the healing work of Yahweh in the period of the Old Testament. The Old Testament and African Indigenous Religion believe that Yahweh is the ultimate healer through prophets, and physicians are also agents of healing on behalf of God. They used words, materials such as water, herbs and touching for healing. The purpose of this article is to examine the Old Testament and African, or Yoruba, tradition to show how Yahweh's healing work is important and that he is the ultimate healer in the Old Testament and African (Yoruba) tradition, although prophets and physicians are also agents of healing on behalf of God. To achieve this purpose, this article used African Biblical Hermeneutic methodology to examine various vocabularies for healing in the Old Testament (ארכה, מרפא, שלום, רפא).

Contribution: Apart from assisting readers to appreciate the healing work of Yahweh in the Old Testament, this article has brought the possibility for readers to appreciate both Old Testament and African (Yoruba) healing, and to attribute them ultimately to God. It can also be used supplementarily to Western orthodox healing, as God is the final healer.

Keywords: healing; health; Old Testament; African traditional religion; Yoruba.

\section{Introduction}

Health is an important aspect of life all over the world. Throughout the Old and New Testament, the words health and healing appear quite often. A close examination of the Old Testament in the Hebrew Bible shows that the subject of health is important and relevant.

In this modern age of science, healing has become secularised to the extent that the meaning of healing is not all that important for human relationship with God. The fact is that, throughout the Old Testament, it is emphasised and accepted that Yahweh is the healer of his people (Ex 15:26; Ezk 34:4; Jr 8:15). ${ }^{1}$ To Christian and non-Christian, health is the highest gift (Westermann1972:9). In the Old Testament and the indigenous Yoruba community, 'healing from illness is an essential part of human existence' and it is 'experienced quite naturally as God's deed' (Westermann 1972:10).

When one examines prestigious books on the Old Testament theology, it appears difficult to find a major section on God as a healer or a significant discussion on the healing work of Yahweh in the period of the Old Testament.

This is probably because the major works on Old Testament theology in the 20th century mainly focus on the mighty acts of Yahweh or salvation history, redemption, election, covenant, liberation, creation and others. As a result, major theological work on God as a healer is difficult to find.

This article aims to examine various terminologies used for health and healing in the Old Testament based on the Old Testament conception of healing, as well as on the African conception of healing among the Yoruba people of Nigeria. To achieve this aim, this article used the African Biblical Methodology. ${ }^{2}$ The agents and methods of healing in the Old Testament and African religious tradition are also examined to establish the possible similarities between the Old Testament and African (Yoruba) health and healing (Gerstenberger 2019:217).

1.However, many believe they have a gift of healing which can be attributed to God.

2.African biblical methodology means approaching the biblical text from an Afrocentric perspective. 


\section{Terminologies for healing in the Old Testament}

From the Old Testament point of view, human body parts are complex structures. The common Hebrew terms for the body (נפש) have a broad semantic meaning - life, mind and soul with various meanings - and occur about 750 times (Renn 2005:128, 918). Other terms are mut, [denoting die or death], nebelah [carcass or corpse], gewiyah, [body either dead or alive], guphah [remains], geshem [human body] and peger which is a synonym for the above terms. What the Old Testament says about the body as part of the human being, which is the subject of health, is important.

One of the most important Hebrew words for the soul, life and mind is and it occurs 750 times in the Old Testament (Renn 2005:597) as mentioned above. This word has a broad semantic range such as 'life', 'soul' and 'mind'. In several instances, it refers to a corpse with which Israelites are forbidden to have direct contact, because it would make them ceremonially unclean ( $\operatorname{Lv} 21: 11 ; \mathrm{Nm} 6: 6 ; 9: 6)$.

\section{The characteristics of good health}

The Old Testament does not present a systematic definition of health or medicine, but rather gives a picture of the characteristics of healthy people as seen in their character, action and life (Wilkinson 1998:11). Even though we cannot find a systematic definition of health in the Bible, we can, however, find how healthy people are portrayed and how to recognise them.

\section{[ישלום [Peace or well-being]}

Peace means well-being which is one of the characteristics of healthy people in the Old Testament. The closest translation is 'well-being' (Van Zyl 2008:315). For the Old Testament writers, the basic characteristic of human beings is life, that is, full life. They do not seem to be interested in discussing the anatomical or physiological function as much as the moral activities and spiritual achievement. What is important is the human quality of life rather than the quantity of life even though its quantity may determine its quality.

The Hebrew word שלום expresses what one may call the quality of the fullness and well-being of life in the Old Testament. It is the word that comes closest to expressing the Old Testament concept of health. This word appears about 250 times in the Hebrew Bible in about 213 separate verses (Davidson 1977:12; Renn 2005:719; Wilkinson 1998:19). This word is most frequently used in the book of Jeremiah (31 times), Isaiah (27 times) and Psalm (27 times) (Wilkinson 1998:11). The word שלום in the Old Testament is derived from שלם which means to be in the covenant of peace (Davidson 1977:780). The King James Version (KJV) translates 172 of these as 'peace'. The word means 'peace, prosperity, wellness, health, completeness and safety' (Lloyd 1980:930-931).

Shalom in the Old Testament has spiritual, social and economic dimensions. The spiritual dimension in the Old
Testament includes all that Yahweh himself is to the people (Hasel 1983:191). It includes blessing, deliverance from sin, sickness and poverty. Yahweh is peace (שלוםיהוה). He is the source of all things. All good and valuable things such as good health, healing, prosperity, contentment, life and death come from him.

\section{ציק[Righteousness]}

The word above is translated as righteousness. It means the state of being righteous or just (Renn 2005:825). It occurs about 200 times in the Old Testament (Renn 2005:826). It describes human beings who walk in an honourable way with God. צדיק means a sense of innocent in contrast to those who are guilty (2 Ki 10:9; $2 \mathrm{Chr} 6: 23$; Is 5:23). It describes the right relationship. When the word refers to God, it means his perfection in all moral and just dimensions. That is why Yahweh is described as the Righteous One (referenced). Righteousness is part of his attributes.

\section{[Oשמע [Obedience]}

שממע is translated as obedience or obey. It is a common and important verb that occurs about 1150 times in the Old Testament (Renn 2005:682). The literal and predominant meaning is 'to hear' or 'to listen'. This word שמע has many nuances. One is to be obedient, mentioned in about 80 contexts and referring to both human and divine planes. Children have to obey their parents and humankind has to obey God. It is also used in a negative sense in the case of human beings refusing to obey God, with punishment as a result (Gn 27:8,13; Ex 23:21; Jr 3:13).

\section{כStrength]}

The above Hebrew word כח is a noun that occurs about 130 times. It means strength, power and might (Renn 2005:935). It refers generally to human strength, energy and vitality, as well as physical strength (see Gn 31:6; Lv 26:20; Job 6:11; Pr 20:29; also see Renn 2005:935). In Psalm 29:11, strength means שלו and in several passages, it is considered as the gift of God (Ex 15:2; 2 Sm 22:33; Is 40:29). It is certain that when the Old Testament mentions strength, it does not simply mean physical strength, but a person's strength throughout their whole being which includes body and wellness.

\section{[Fertility]}

In Deuteronomy 7:12-14, exceptional fertility is promised to those who obey the law of God. According to this passage, if the children of Israel listen, obey and keep the commandment of Yahweh, he will love them, bless them and multiply them. None of them will be barren, and sickness will be kept away from them (Dt 7:12-14).

\section{[Longevity]}

Another important characteristic of health is a long life. A long life was promised to Abraham as part of shalom (Gn 15:15) and that is why he led a full life and died at an 
advanced age (Gn 25:8). A long life was promised to those who obey God's law (Ex 20:12; Dt 5:16; 1 Ki 3:14; Pr 3:1-2).

\section{Four major Hebrew words used in the Old Testament for healing}

A close examination of the Hebrew text shows that there are four Hebrew words used in the Old Testament for healing. These words are שלום ,מרפא, ארכה and רפא

\section{רפא [Healing]}

Exodus 15:26, which appears to be the root verse of רפ, seems to be the most important foundation of the Old Testament theology of healing. Karl Barth called it 'the divine Magna Carta in all matters of health questions' (cited by Wilkinson 1998:53). The most important part of the verse is the last sentence כי אני יהוה רפאך (Ex 15:26).

The word רפאך, as it is used in the sentence, is kal, participle, active, singular, masculine with suffix second person singular (Hamilton 2011:243-244). I would like to translate it to 'because I am Yahweh your healer' or 'because I am Yahweh the one healing you'. Exodus 15:26) shows that Yahweh has the prerogative to cause sickness and to heal (Oguntoye 2013:31). The word with its various nouns and verbs derivatives of the root word רפא, appears about 86 times in the Hebrew Old Testament text (Harris, Archer, Waltke 1980:587; Wilkinson 1998:53-54). The meaning appears to be the most straightforward one used for healing in the Old Testament.

Unlike other words used for healing in the Old Testament, it has a purely Hebrew root. In many occurrences of this word, God is the one who caused the healing and humankind became the object of that healing (Harris et al. 1980:587; Wilkinson 1998:53-54).

However, this is not to say that there is no debate among scholars about its basic meaning. One view maintains that the basic root means 'to stitch together'. It is further explained that the application of the root 'to heal', came from the practice of stitching the edges of wounds together to restore skin continuity. (Wilkinson 1998:52). From this root, the term means physician (Gn 50:2, Ex 15:26; 2 Chr:12; Jr 8:22), as well as medicine. Although this will aptly describe a physician, there is no evidence that a specialist physician such as a surgeon existed in ancient Israel (Wilkinson 1998:57-58).

Another view is that the primary root of רפא means to 'restore', 'to make whole' and 'to heal' (Abogunrin 2004:1-31). The fact is that this usage is also prominent in the Old Testament text (Wilkinson 1998:53). This view seems to explain why humankind is always the subject of healing as is in Genesis 20:17, Exodus 21:19 and 2 Chronicles 30:20. From the observation above, the root means 'to heal', 'to cure' and 'to restore to prosperity' (Wilkinson 1998:53). This restoration could also mean restoration in a spiritual sense from the neglect of the Ten Commandments of God. It could also mean restoring comfort or to console as in Job 13:4 (Briggs, Brown \& Driver 1977:950; Davidson 1977:689; Harris et al. 1980:587).

\section{[Cure] or ארכה [Extension]}

ארכה . These two words are also used infrequently for healing comes from the root word ארד. This is a rare noun that occurs only six times in the Old Testament. It means healing, soundness and health in four of these six instances (Davidson 1977:46). The root's meaning is 'to belong', 'to make long' ארכה is used in Isaiah 58:8, Jeremiah 8:22, 30:19 and 33:6 with a sense of repairing, restoring and healing (Davidson 1977:47). מרפא appears about 15 times in the Old Testament with 'health' and 'healing' as the meaning (Renn 2005:473).

When used negatively, the meaning is 'incurable'. The term is used both literally and metaphorically. The literal use is in the book of Jeremiah 8:15 and the negative use in 2 Chronicle 21:18 referring to 'incurable disease'. The prophet, Jeremiah, mentioned that their hope of healing for the children of Israel will be fulfilled as a result of God's judgement (Jr 4:19; Frechette 2015:3). In Proverbs 12:18 and 16:24, it is used metaphorically in the sense of peace of mind and in Jeremiah 33:6 for the promise of renewal.

\section{הבשיש [Binding]}

literarily means 'to bind' and 'bind round about', especially with ropes as a headdress (Ex 29:9; 8:13). It has a concept of 'binding up' a wound, for example. It means to stop, to restrain or to bandage. In Isaiah 1:6, 30:26, Ezekiel 39:21 and Hosea 6:1, it refers to healing which is promoted by covering the wound with bandage. Hosea 6:1 says לכו ונשובה אל-

\section{Agents of healing in the Old Testament \\ Yahweh as the direct agent of healing}

Throughout the Old Testament, Yahweh is considered as the healer - whether by means of materials or not. There are many occasions when he heals directly, especially barren women. One example is Sarah in Genesis 18:11-14; 21:1-2. The barren women of Abimelech's household became pregnant (Gn 20:17-18 - New Revised Standard Version [NRSV]). Rebekah and Rachel became fertile by praying to Yahweh (Gn 20:17-18 - NRSV). More elaboration will be given later in this article.

\section{Prophets as agents of healing}

Prophets of the Old Testament heal the sick either by giving advice or by carrying out healing procedures themselves. Elisha advised Naaman, the Syrian army commander, to wash in the Jordan River and that led to the cure of his leprosy $(2 \mathrm{Ki}$ 5:1-14). Another example of prophetic advice for healing is Isaiah's advice to King Hezekiah who applied a fig poultice to his boil (Is 38:21). With a combination of prayer and application of a fig poultice, Hezekiah was also healed (2Ki20:7; Is 38:21). 


\section{Physicians as agents of healing}

Although physicians are not prominent in the Old Testament text, their existence is acknowledged, and their activities and worth are not denied. This is in contrast with the place of physicians in Mesopotamia and Africa, particularly in Egypt, and the post-biblical times where their presence is not only acknowledged, but also prominent.

People were advised not to live in a place where there was no physician (Gaiser 2010:59-60). During this period, Ben Ahijah/ben'Ahiyah, a physician, was given the task of treating the bowel sickness of the priest in the Temple at Jerusalem (Gaiser 2010:49).

It is sometimes claimed that doctors in the Old Testament were not highly regarded because of their basic interpretation of some Old Testament passages such as Job 13:14 and 11 Chronicles 16:13. However, because they were not so prominent does not mean that they were not highly regarded in ancient Israel. A passage in one of the Old Testament Apocrypha Ecclesiasticus made clear their worth around the 2nd century BCE. The author, Jesus ben Sirach, scholar and scribe, discussed how the Jewish attitude towards physicians should be. Ecclesiasticus advised the people to honour physicians, because it was God who gave them their calling (Ec 38:1-3).

\section{Ways and materials used to heal Healing by words}

The Old Testament view is that Yahweh is the healer of all diseases, even those who are healed through prophets, physicians, through different means or materials such as herbs, water and symbolic actions. However, there are various occasions when Yahweh healed directly. Most of the time it has to do with fertility as mentioned earlier.

That is why God said אני יהוה רפאך [I am the Lord your healer] (Ex 15:26). When Abraham and his wife were already old and had passed the age of childbearing, Yahweh promised Abraham, 'I will surely return to you about this time next year and Sarah your wife will have a son' (Gn 18:10). The Lord fulfilled his promise and Sarah became pregnant in her old age and bore Isaac (Gn 21:1-2).

The barren women of Abimelech's household became pregnant. Abraham prayed for Abimelech and his wife, and God healed both the wife and female slaves (Gn 20:17).

Rebekah and Rachel became fertile by the grace of Yahweh and because of Isaac's prayer. Both Rebekah and Rachel became pregnant and bore children (Gn 25:21; 30:22-23).

The Shunammite Woman bore a son by Elisha's pronouncement (2 Ki4:8-17).

\section{Healing by touch or body contact and prayer}

The widow's son in 1 King 17:7-24 was healed by Elijah when her son died. When she reported the death to the prophet
Elijah, he got hold of the dead child and took him to the upper room, laid the child on his bed, stretched himself out on the body of the deceased three times and cried to the Lord to revive him. The dead boy came alive (1 Ki 17:20-21 - NRSV). Elijah then returned the boy to his mother. Wilson (1998:60) considered this process to be an 'artificial cardio-respiratory resuscitation'.

With these miracles of raising a dead child and the multiplication of oil and bread, Elijah demonstrated that he acted by the power of Yahweh as was the testimony of the widow: "Then the woman said to Elijah, "Now I know that you are a man of God and that the word of the Lord from your mouth is the truth"' (1 Ki 17:24; Collins 2004:264).

The story demonstrates the power of symbolic action and the supplicatory prayer of Elijah. It also affirms the name of Elijah as the man of God, and that his God is the true God to serve and not Baal.

The Shunammite dead boy was raised from the dead by Elisha (2 Ki 4:18-36) by an 'artificial cardio-respiratory' resuscitation on the son. He lay upon the child, 'put his mouth upon his mouth, his eyes upon his eyes, and his hands upon his hands', and the boy was raised from death 'instantly' (2 Ki 4:33-35 - NRSV).

\section{Healing by means or material}

Yahweh is not limited in his power. He can use any means for healing. For example, the children of Israel had just escaped from the Egyptians at the Sea of Reed and marched for three days to the wilderness of Shur or Etham (Nm 23:8). At Marah, they found bitter, undrinkable water. When the children of Israel complained, Yahweh showed Moses a tree that he had to cut down and throw into the water. The water then became drinkable. After the water of Marah was sweetened, Yahweh promised not only to heal the Israelites, but to keep diseases far away from them if they keep his commandments (Ex 15:26).

Five important things are worth noticing in the above promise of Yahweh: (1) the promise was conditional to their obedience; (2) the promise was to prevent diseases; (3) these are specific diseases similar to the ones suffered by the Egyptians; (4) it implies that Yahweh himself can afflict people; and (5) there was an assurance that if the people get sick, Yahweh can heal them. This promise was a result of the dissatisfaction of the people. It means that not all the healing is subject to their obedience (Ex. 15:24). Muntner (1977:9), the Jewish physician, estimated that out of 613 biblical commands and prohibitions, no less than 213 of them are health related.

\section{Healing by looking at a serpent of bronze (Nm 21:4-9) ${ }^{3}$}

Israel murmured many times, but Yahweh responded positively. He sweetened the bitter water of Marah 3.This story is believed to be a composite narrative belonging to Yahwistic and Elohistic sources (Marsh 1980:242) 
(Ex 15:22-25). He provided bread or manna from heaven (Ex 16:2-12) and water from the rock (Ex 17:1-7).

However, when they murmured against Moses, God sent a poisonous snake to bite them, and many died ( $\mathrm{Nm}$ 21:6). When they call out to Moses, he prayed to God and God instructed Moses to make a serpent of bronze for healing (Nm 21:9). Anyone bitten by the poisonous snake could look at the bronze snake and live ( $\mathrm{Nm}$ 21:9).

While the snakes in the wilderness were symbols of death, it was a symbol of temptation in the garden of Eden (Nm 21:9). Snakes were generally associated with seraph which generally means 'fiery' (Is 6:1-6). Seraphs are pictured in Isaiah 6:1-8 as God's servants and attendants, and therefore one can view the snakes in the wilderness as the divine messengers of God to bring rebellious Israel to God (Gaiser 2010:40). According to Fretheim (1978:270), this use of snakes for divine judgement should not be seen as 'separable forensic responses to each evil deed', but as God's view to maintain fundamental moral order. God uses bronze snakes as a form of healing intervention.

\section{Elisha's healing of a large poisonous pot of stew}

During a famine, the prophet, Elisha returned to Mount Gilgal where a company of prophets was meeting (2 Ki 4:38). He ordered them to cook for these prophets using a large pot for the stew made of poisonous wild vine (2 Ki 4:38). As the company of prophets ate the stew, they called out, 'oh man of God there is death in the pot' (2 Ki 4:38-42), because it was made of the poisonous wild vine. Elisha, the man of God, fixed the stew with flour and the food was not harmful anymore (2 Ki 4:42-44).

King Hezekiah was healed by prayer and a lump of figs ( $2 \mathrm{Ki}$ 20:7, 21): The king's response to his illness was a prayer to Yahweh. He faced the wall and wept bitterly. Yahweh heard his prayer. He sent the prophet Isaiah back to him to tell him the good news that he would add 15 years to his life. The prophet Isaiah said, 'Prepare a lump of figs. They did so and applied it to the boil and he recovered' (2 Ki 20:7).

The Prophet Elisha healed Naaman, the commander of the Syrian army, of leprosy with water (2 Ki 5:1-14-19; Ogunkunle 2004:51-63).

\section{Healing in an African (Yoruba) context}

\section{African medical tradition}

The origin and evolution of healing as a specialised skill is the oldest in the world (Adodo 2010:66). Hippocrates was considered the 'father of Medicine', but when Breasted translated the Edwin Smith papyri in 1930, it became clear that Imhotep, the African Egyptian who antedates Hippocrates by 2500 years was rather the 'father of Medicine' (Adodo 2010:66). The Edwin Smith Eber papyrus, dating back to the pre-pyramid times (about 4000 years ago), are the most important medical documents of ancient
Egypt (Adodo2010:66). Imhotep was the adviser of Pharaoh Djoser who was a statesman and the builder of the world's great edifice of stone called the step-pyramid of Sakkarah in Egypt (Adodo 2010:66). Hippocrates was said to have descended from the line of 'Asclepiads', the devotees of the Greek healing god 'Asclepiads' who is often identified with Imhotep.

Egyptians were writing medical textbooks as early as 5000 years ago, and the Athenians used to import physicians to the cities of the ancient Near East, Rome and Europe (Adodo 2010:67). There is a mixture of magico-spiritual and rational elements in ancient Egyptian medicine for healing, because about $60 \%$ of illnesses has a psychic base and placebo medicine arose from this (Adodo2010:66). Rulers of ancient Egypt surrounded themselves with physicians to ensure their well-being, and the methods of healing used for medical cures range from the use of potent words, herbs and rational diagnosis (Adodo 2010:66).

There is a dispute as to whether ancient Egyptians transported their medicine and civilisation to Sub-Saharan Africa (Adodo 2012:70). Ancient Egyptian movements were not limited to the ancient Near East, Rome and Europe (Adodo 2010:70-71). They also transported their medical ideas to sub-Saharan Africa (Adodo 2010:70-71). The inscription of Ameni, which was written during the Sixth Dynasty of the reign of Pepi II, mentioned that the king travelled to the south to overthrow 'the abominable Kash' and to obtain tributes (Breasted 1906:317-318).

The medical practice in sub-Saharan Africa is a combination of magical, mythical, spiritual and scientific activities (Adodo 2010:71). African (Yoruba) medicine involves the use of herbs, sacred chants, potent words, dance and touch. In many parts of Africa, medicine also involves the use of animal parts such as the liver, kidney, gall bladder and a gizzard that is burnt to ashes. A cow's tail and liver are, for example, burnt to ashes for the healing of diabetes, because these organs are said to be high vibratory organs with high electromagnetic fields. Using them as medicine is a way of transmitting these energy waves for healing the diseased organs (Adodo 2010:72). These animal parts are sometimes added to herbal ingredients for various illnesses (Adodo 2010:72).

According to the Yoruba legend, the earliest form of healing in Africa is vibrational healing developed by Orunmila who became the founding father of Yoruba medicine (Adodo 2010:73). According to the Yoruba legend, Osanyin also has the gift of communicating with plants and was good at the knowledge of herbs and how to use the energy of plants for healing (Adodo 2010:72). Africans believe that sickness is caused as a result of disharmony between the physical and the spiritual, and the task of the physician is to restore this disharmony. After finding the cause of this disharmony, the person was then treated which may involve oracular processes such as 
the consultation of Ifa oracle, counselling, rituals, dance, prayers and the confession of guilt (Adodo 2010:75).

\section{Yoruba people of Nigeria}

Yoruba people live mainly in the southwestern part of Nigeria and some other states such as the Kogi and Kwara states. Others live in Benin and Sierra Leone. They are the largest ethnic group in sub-Saharan Africa (Bascom 1969:1). They are the most important groups in West Africa not only in terms of numbers, but also in terms of significance and contemporary world influence (Booth 1977:179; Ilega 2000:105-138; Olubunmi 2011:4-6). There are more people committed to the Yoruba religion outside Africa than in Nigeria. They are called Nago in Brazil, Aku in Sierra Leone and Lucumi in Cuba (Kilson \& Rotberg 1976).

\section{African religion and tradition}

The Yoruba song below tells what peace means in the African context.

Table 1 mirrors a common song among the Yoruba people that tells the importance of peace, as well as healing, because, without peace, there is no health (Adamo 2004:36). According to the Yoruba people, peace is the most important thing in human beings (Adamo 2004:36).

For us to appreciate healing in the Old Testament and the African context, it is important to briefly discuss the therapeutic system in the African indigenous culture.

As in the Old Testament, healing in the African (Yoruba) indigenous culture is a corporate matter which involves the totality of the person, the family and the community (Adamo 2004:35). This is what I may call the concept of corporate responsibility in the African health system. Healing in the African tradition is peace as it is in the Old Testament.

Good health in the African indigenous concept differs remarkably from the Western concept. While the World Health Organisation (WHO) (n.d.) defines good health as 'a state of complete physical, mental and social wellbeing and not merely the absence of disease or infirmity', the African concept has to do with the state of total physical, mental, economic and social well-being as a result of the maintenance of a good relationship and harmony with nature, divinities, spirits and fellow beings

TABLE 1: Important song of peace.

\begin{tabular}{ll}
\hline Alafia & Translation \\
\hline Maa ko 'le & I will build a house \\
Maa bi 'mo & I will bear children \\
Lai si Alafia moto ayokele & I will buy motor cars \\
Iwon yen ko sese & Without peace [shalom] \\
Alafia loju & Those things are impossible \\
Ile'raloro & Peace is the most important \\
Eni ti o ni Alafia & Health is wealth \\
Olohungbogbo & He who has peace (shalom) \\
\hline
\end{tabular}

Source: Adamo, D.T., 1990, 'Peace in the Old Testament and African Heritage', in H.W. Kinoti \& J.M. Walligo (eds.), The Bible in African Christianity, p. 11, Action Press, Nairobi.
(Silis 1972:95). Therefore, health involves the physical, the psychological, the spiritual and the environmental (Adamo 2018:10). In the African context, lack of good health can be classified into three categories: the natural, the supernatural and the mystical (Adamo 2004:36). The natural or physical means the mere dysfunction of the physical system or injury caused by accident (Adamo 2004:36). This type of condition will normally respond to medicine quickly. The supernatural and mystical diseases are the ones caused by witches and wizards, and by breaking taboos or neglecting one's responsibilities to ancestors, as well as disharmony with fellow human beings (Adamo 2018:10). These are usually difficult to treat except with a special combination of herbal treatment and ritual, confession, sacrifices and special restoration of harmony with God and divinities, spirits and the entire environment. Before the advent of Christianity and Western orthodox medicine, Africans have developed certain effective ways of rescuing themselves from these types of diseases, and these means are not doubted (Dopamu 1988:216). These ways include the use of herbs, powerful, mysterious or potent words (ofo, and other rituals of restoration of the harmony among the people and the environment; ogede, animal parts, living and non-living things, water, fasting, prayers and laying of hands). Among the Yoruba people, healers are called Onisegun, Elegbogi or Oloogun (Dopamu 1988:216). While Onisegun and Oloogun literally mean the one who possesses medicine or herbs, Elegbogi means the one who owns the root of trees (Dopamu 1988:216).

They are medicine men or women who are professional healers and good in the art of healing, either by herbs or ofo (Dopamu 1988:217). Generally, almost every adult in the traditional society possesses some knowledge of herbs, roots or ofo to cure diseases, and it is used privately by individuals or families, but when the disease becomes mysterious or inexplicable, or does not respond positively to treatment, sacrifices are offered to the gods (Dopamu 1988:216).

The use of potent words, ofo or ogede for therapeutic purposes is not uncommon among African indigenous people (Olatunji 1984:139-140). These words must be uttered in a specific place, at a specific time and in a specific way for them to be effective (Olatunji 1984:140). It may also involve ritual performances (Olatunji 1984:140).

See Tables 2 and 3 for examples of the use of the potent words, ofo or ogeed, for healing scorpion sting or headache. One should chew seven alligator peppers and placing one's mouth on the patient's navel and recite the potent words above (Adamo 2012:14).

A non-Yoruba or non-African may doubt this, but the Yoruba people who have seen it at work, will not. Many biblical scholars believe in the power of words. For example, Edmond Jacob, Von Rad, Eichrodt, Knight and Bultmann believe in the power of spoken words to perform some mysterious things. They emphasised that the spoken word in ancient Israel was never 'an empty sound but an operative reality whose actions cannot be hindered once it has been pronounced' (Jacob 1958:127; Knight 1953:14-16; 
TABLE 2: Example of potent words for healing scorpion bite.

\begin{tabular}{ll}
\hline Oorun lode l'lalamuwonu & Translation of the potent words for healing \\
\hline Oorun lode l'alamuwonu & $\begin{array}{l}\text { It is the sun that rises that made the lizard } \\
\text { comes in }\end{array}$ \\
Oorunkujualaamu jade (7 times) & The sun sets and the lizard comes out (7 times) \\
\hline
\end{tabular}

Oorunkujualaamu jade (7 times) The sun sets and the lizard comes out (7 times) Source: Adamo, D.T., 2012, 'Decolonizing Psalm 91 in an African perspective with specia Adamo, D. 2020 ,'Decolonizing Psalm 8 in an African (Yoruba) context', Journal of Semitic Studies 29(2), 19. https://doi.org/10.25159/2663-6573/7613

TABLE 3: Example of potent words to drive away all evil.

The use of leaves with potent words Translation of the potent words

O leweoroloun o maa fir o gbogbobi He says it is the oro leaves that he will use danu to push all evil away

Loogan-o ounni o maa gangbogboarun He says it is ogan-o [Benin mahogany] that da nu He says it is ogan-o [Benin mahoga
he will use to cut off all diseases

O nikannu in naani o maa kangbogbo He says it is potash that will break off all evil bi da

O IOyekuMejiloun o yaa maa fi ye He says it is Oyeku Meji that will take the ibidaalee evil away

Source: Olatunji, O., 1984, Features of Yoruba oral poetry, p. 161, University Press Limited Ibadan.

TABLE 4: Example of some herbs for various diseases.

\begin{tabular}{ll}
\hline Names of diseases & Method of use \\
\hline Malaria fever & $\begin{array}{l}\text { Squeeze yellow pawpaw leaves in water. } \\
\text { Take a cup full three times daily for seven } \\
\text { days. }\end{array}$ \\
Asthma & $\begin{array}{l}\text { Burn dried pawpaw leaves. Inhale the } \\
\text { smoke during an asthma attack. To } \\
\text { prevent an asthma attack, inhale the } \\
\text { smoke every night. }\end{array}$ \\
Kidney problems, prostatitis, & $\begin{array}{l}\text { Cut plantain root and squeeze the juice } \\
\text { and mix with half a bottle of honey. Take } \\
\text { two tablespoons full three times daily. }\end{array}$ \\
Earache & $\begin{array}{l}\text { Lemon leaves juice, drops of honey, } \\
\text { ginger, clove, and apply drops in the ear. }\end{array}$ \\
\hline
\end{tabular}

Source: Adodo, A., 2012, Nature power, pp. 33; 86, Benedictine Publications, Ewu-Esan; and Aduku, A.O., Bolorunduro, P.I. \& Booth, S.A, 2017, Food is medicine, p. 51, T.W Press \& Publishers, Kaduna.

Von Rad 1965:85). Von Rad (1965:85) said, 'Israel's theologians and prophets were, of course, certain that, for all the mysterious possibilities inherent in every word of man, the word of Yahweh towered comparably high above them.'

This is supported by Isaiah 55:11 that indicates that the word that goes out will not go without accomplishing its purpose. It means that the spoken words are not empty sounds.

Many problems are experienced with herbal medicine (Table 4). Firstly, it is difficult to identify which herb heals which disease. However, most herbalists (called Babalawo in the Yoruba language) always claim to have been in spirit and spirits teach them which herb cures which disease. Secondly, there is the problem of lack of standardisation and safety. Thirdly, it is technically difficult to accurately determine the amount of chemical ingredients in an herb. Fourthly, there is a lack of scientific proof of its efficacy. The fact that an herb works for a kind of treatment is not enough. It is important to know how it works. Fifthly, most herbal medicines have no precise dosage.

\section{Conclusion}

This article has discussed the concept of health and healing in the Old Testament by mentioning the various terminologies used for health and healing. Yahweh, prophets and physicians are the main agents of healing in the Old
Testament. The methods used in the Old Testament and the African tradition, which were employed for healing, for example words, prayers, water and herbs, are also discussed.

From the above study, is concluded that the ancient Hebrew tradition resembles that of the African tradition. What is worth noting, is that, unlike the Eurocentric concept of healing, the Hebrew and African concepts of healing denote completeness. Healing encompasses the spiritual, physical, economic and all that life entails, that is, the total well-being of an individual and a society. Like the Hebrew concept of healing, African Christianity has both the social, spiritual, physical and economic dimensions.

The spiritual dimension of shalom in the African continent involves the healing of Africa through righteousness, justice and redemption from sin. The social and economic dimensions of shalom in Africa can come because of righteousness (Is 32:17). The very economic dimension of shalom in Africa is tied together by wholeness, safety, prosperity and good physical health. If there is no good food, no tolerance, no justice and no righteousness, there cannot be any well-being or good health. There cannot be peace. The economic dimension of shalom is the most important meaning in Africa which is followed by the spiritual dimension. There cannot be peace or general good health without good leadership to manage our resources. This is lacking in most African countries.

\section{Acknowledgements Competing interests}

D.T.A. declared that no competing interest exist.

\section{Author's contributions}

D.T.A. declares that he is the sole author of this research article.

\section{Ethical considerations}

This article followed all ethical standards for research without direct contact with human or animal subjects.

\section{Funding information}

This research received no specific grant from any funding agency in the public, commercial or not-for-profit sectors.

\section{Data availability}

The author confirms that the data supporting the findings of this study are available within the article.

\section{Disclaimer}

The views and opinions expressed in this article are those of the authors and do not necessarily reflect the official policy or position of any affiliated agency of the authors. 


\section{References}

Abogunrin, S.O., 2004, 'Healing in African context', in S.O. Abogunrin, J.O. Akao, D.O. Akuntunde, G.N. Toryough \& R.A. Oguntoye (eds.), Biblical healing in African context, pp.1-30, Nigerian Association for Biblical Studies, Ibadan.

Adamo, D.T., 1990, 'Peace in the Old Testament and African Heritage', in H.W. Kinoti \& J.M. Walligo (eds.), The Bible in African Christianity, pp. 99-11, Action Press, Nairobi.

Adamo, D.T., 2004, 'Healing in the Old Testament,' in S. Abogunrin, J.O. Akao, D.O. Akintunde, G.N. Toryough \& R.A Oguntoye (eds.), Biblical healing in African context, pp. 32-50, Nigeran Association for Biblical Studies, Ibadan.

Adamo, D.T., 2012, 'Decolonizing Psalm 91 in an African perspective with special reference to the culture of the Yoruba people of Nigeria', Old Testament Essays 25(1), 9-26

Adamo, D.T., 2018, 'Reading Psalm 23 in an African context', Verbum et Ecclesia 39(1), 1-13. https://doi.org/10.4102/ve.v39i1.1783

Adamo, D.T., 2020, 'Decolonizing Psalm 8 in an African (Yoruba) context', Journal of Semitic Studies 29(2), 1-21. https://doi.org/10.25159/2663-6573/7613

Adodo, A., 2010, Herbal medicine, and revival of African civilization, Pax Herbal Publications, Ewu-Esan.

Adodo, A., 2012, Nature power, Benedictine Publications, Ewu-Esan.

Aduku, A.O., Bolorunduro, P.I. \& Booth, S.A, 2017, Food is medicine, T.W Press \& Publishers, Kaduna.

Bascom, W., 1969, The Yoruba of South-Western Nigeria, Holt Rinehart \& Winston, New York, NY.

Booth, N.S. (ed.), 1977, God and the Gods in West Africa, NOK Publishers, New York, NY.

Breasted, J., 1906, Ancient records of Egypt, vol. 2, University of Chicago Press, Chicago, IL.

Briggs, C.A., Brown, F.\& Driver, S.R., 1977, Hebrew and English Lexicon, Claredon Press, Oxford.

Collins, J., 2004, Introduction to the Hebrew Bible, Fortress Press, Minneapolis, MN.

Davidson, B., 1977, Analytical Hebrew and Chaldee Lexicon, Zondervan Publishing House, Grand Rapids, MI.

Dopamu, A., 1988, 'The place of Onisegun in the Yoruba Health care system', in I.A.B. Balogun, A. Dopamu, R. Akanmidu \& I.O. Oloyede (eds.), The place of religion in the development of Nigeria, pp. 216-235, Publication of the Department of Religions, University of Ilorin, llorin.

Frechette, C.G., 2015, 'The Old Testament as controlled substance: How insights from trauma studies reveal healing capacities in potentially harmful texts', Interpretation: A Journal of Bible and Theology 69(1), 1-19. https://doi. Interpretation: A Journal of Bible
org/10.1177/0020964314552624

Fretheim, T.E., 1978, 'Life in the wilderness', Dialog 17(4), 270.

Gaiser, F.J., 2010, Healing in the Bible, Baker Academic, Grand Rapids, MI.

Gerstenberger, E.S., 2019, 'Shamanism and healing experts: Notes on healing in the Old Testament', Religion and Theology 26 (3-4), 216-232.https://doi org/10.1163/15743012-02603006
Hamilton, V.P., 2011, Exodus: An exegetical commentary, Baker Academic, Grand Rapids, MI.

Harris, R.L., Archer, G. Jr. \& Waltke, B.K., 1980, Theological wordbook of the Old Testament, Moody Bible Institute, Chicago, IL.

Hasel, G.F., 1983, 'Health and healing in the Old Testament', Andrews University Seminary Studies 21(3), 191-202.

Ilega, D.I., 2000, Yoruba religious tradition: West African religious tradition, Hamaz Global Ventures, Ado Ekiti.

Jacob, E., 1958, Theology of the Old Testament, transl., A.W. Weathcote \& P.J. Alcock, Harper \& Row, New York, NY.

Kilson, M.L. \& Rotberg, R.I., 1976, The African diaspora, Harvard University Press, New England.

Knight, G.A.F., 1953, A biblical approach to the doctrine of the trinity, T\&T Clark, Edinburgh.

Lloyd, C., 1980, 'Shalom', in R.L Harris, G. Archer \& B. Waltke (eds.), Theological Wordbook of the Old Testament, pp. 930-931, Moody Bible Institute Press, Chicago, IL.

Marsh, J., 1980, 'The book of Numbers', in G.B. Buttrick (ed.), The Interpreter's Bible, pp. 117-308, Abingdon Press, Nashville, TN.

Muntner, S., 1977, 'Medicine in Ancient Israel', in F.Rostner (ed.), Medicine in the Bible and Talmud, pp. 9-15, Ktav Publishing House, New York, NY.

Ogunkunle, C.O., 2004, 'Prophet Isaiah and the healing of Hezekiah in African context', in S.O. Abogunrin, J.O. Akano, D.O. Akintunde, G.N. Toryough \& P.A. Oguntoye (eds.), Biblical healing in African context, pp. 33-63, The Nigerian Association for Biblical Studies, Ibadan.

Oguntoye, P.A., 2013, 'A theological evaluation of medication and Healing in the Old Testament and its implications for African Indigenous Churches (AIC)', Ogbomosho Journal of Theology XVIII(2), 31-50.

Olatunji, O., 1984, Features of Yoruba oral poetry, University Press Limited, Ibadan.

Olubunmi, A.O., 2011, The rise and fall of the Yoruba Race (10000 BC-1960, The 199 Publishing Palace, Ibadan.

Renn, E.S., 2005, Expository Dictionary of Bible words, Hendrickson Publishers, Peabody, MA.

Silis, D.C., 1972, International encyclopaedia of social sciences, vol. 5 \& 6, Macmillan Press, New York, NY.

Van Zyl, D.C., 2008, 'Holistic healing: Old Testament insights on sickness and healing for churches in Africa confronted by HIV/AIDs', Scriptura 99(2008), 312-320.

Von Rad, G., 1965, Old Testament Theology, vol 2, T\&T Clark, Edinburgh.

Westermann, D.C. 1972, 'Salvation and healing in the community: The Old Testament understanding', International Review of Mission 61(241), 9-19.

Wilkinson, J., 1998, The Bible and healing, The Hansel Press Limited, Edinburgh.

Wilson, R.R, 'The former prophets: Reading the Books of Kings', in J.L. Mays, D. Peterson \&K. Richards (eds.), Old Testament interpretation: Past, present, and future, essays in honour of Gene Tucker, pp. 83-96, Abingdon Press, Nashville, TN.

World Health Organization (WHO), n.d., Definition of health, viewed 08 October 2020, from https://8fit.com/lifestyle/the-world-health-organization-definition-ofhealth/. 